Alexander Borisovich GURKIN

Saint Petersburg State Institute of Technology (Technical University)

Saint-Petersburg, Russia

rpgurkin@mail.ru

ORCID 0000-0001-5194-8043

Konstantin Nikolaevich SKVORTSOV

Saint Petersburg State Institute of Technology (Technical University)

Saint-Petersburg, Russia

skvork@mail.ru

ORCID 0000-0001-8597-264X

https://doi.org/10.34739/dsd.2019.01.02

ОБРАЗ ПОЛЫШИ В СОВРЕМЕННЫХ РОССИЙСКИХ

СРЕДСТВАХ МАССОВОЙ ИНФОРМАЦИИ И ЕГО

ОТРАЖЕНИЕ В ОБЫДЕННОМ СОЗНАНИИ

РОССИЙСКОГО СТУДЕНЧЕСТВА

\begin{abstract}
АннотАция: В статье рассматривается образ Польши, поляков и российско-польских отношений, формируемый российскими СМИ в настоящее время. Чтобы проанализировать этот образ, авторами был рассмотрен ряд публикаций на данную тему, появившихся в российских изданиях в 2014-2018 гг. При этом невозможно было обойти стороной исторические причины российско-польских противоречий, начиная с раннего средневековья и заканчивая XX веком. Авторами оценивается актуальность исторического наследия для современной политики двух стран. Делается попытка определить влияние создаваемого в российских СМИ образа Польши на обыденное сознание учащейся молодежи России. Для этого был проведен опрос студентов первого курса Санкт-Петербургского технологического института. Результаты опроса и комментарии к ним приводятся в настоящей статье.
\end{abstract}

КЛЮЧЕВЫЕ СЛОВА: российско-Польские отношения, российские средства массовой информации, российское студенчество, стереотипы обыденного сознания

\title{
THE IMAGE OF POLAND IN MODERN RUSSIAN MASS MEDIA AND AMONG RUSSIAN STUDENTS
}

\begin{abstract}
The article discusses the image of Poland, the Poles, and Russia-Poland relations, presented by the Russian mass media in recent years. To analyze this image, the authors reviewed a number of publications that appeared in Russian publications in 2014-2018. At the same time, it was necessary to recall the historical causes of the Russian-Polish contradictions, from the early Middle Ages to the 20th century. The authors assess the relevance of the historical heritage for the modern politics of the two countries and make an
\end{abstract}


attempt to determine the influence of the image of Poland created in the Russian media on the everyday consciousness of the Russian students. For this, a survey of first-year students of the St. Petersburg State Technological Institute was conducted. The survey results and comments are provided in this article.

KEYWORDS: Russia-Poland relations, Russian mass media, Russian students, stereotypes

\section{OBRAZ POLSKI WE WSPÓŁCZESNYCH ROSYJSKICH ŚRODKACH KOMUNIKACJI MASOWEJ ORAZ WŚRÓD ROSYJSKICH STUDENTÓW}

ABSTRAKT: Artykuł poświęcony jest wizerunkowi Polski, Polaków oraz stosunkom polskorosyjskim, prezentowanym przez media rosyjskie w ciągu ostatnich lat. Aby zaprezentować ten obraz, autorzy przeanalizowali szereg publikacji, które ukazały się w latach 2014-2018. Jednocześnie nie można było zignorować historycznych przyczyn rosyjsko-polskich sprzeczności, poczynając od wczesnego średniowiecza, a kończąc na XX wieku. Autorzy podjęli również próbę określenia tego obrazu wśród rosyjskiej młodzieży. W tym celu przeprowadzono ankietę wśród studentów pierwszego roku Petersburskiego Państwowego Instytutu Technologicznego. Wyniki ankiety i komentarze przedstawiono w artykule.

SŁOWA KLUCZOWE: stosunki polsko-rosyjskie, rosyjskie środki komunikacji masowej, rosyjscy studenci, stereotypy

\section{ВВЕДЕНИЕ}

За последние годы отношения между Россией и Польшей заметно ухудшились. Существующий издавна узел противоречий снова начал затягиваться, на что не могли не обратить внимания публицисты обеих стран. Одной из популярных тем в средствах массовой информации стали поиски причин российско-польской конфронтации в настоящем и прошлом двух государств, взаимные обвинения и попытки оценить «степень вины» каждой из сторон. Звучащие при этом мнения и оценки бывают очень и очень далеки от объективных и способствующих компромиссу. Однако насколько рисуемая СМИ картина противоречий отражается в обществе? Не является ли эта историко-политическая баталия «игрой для своих», то есть довольно узкого круга политиков и журналистов? Можно ли в данном случае говорить о манипулировании общественным мнением?

Уверенные ответы на поставленные вопросы способно дать только обширное исследование. Авторы настоящей статьи всего лишь попытались приблизиться к этой грандиозной проблеме, изучив малую часть продукции российских СМИ и проведя опрос ограниченной социальной группы жителей России - студентов-первокурсников технического вуза.

Учитывая то, что современная молодежь мало смотрит телевидение и фактически не интересуется печатными периодическими изданиями, мы решили сделать акцент на интернет-публикациях, с которыми опрошенные студенты если и не знакомятся 
напрямую, то по крайней мере соприкасаются через различные подборки новостей на интернет-площадках, пользующихся спросом у молодежи.

Анализу подвергся ряд посвященных польско-российским отношениям публикаций, которые появились в российских СМИ в 2014-2018 гг. Следует заметить, что польская тема занимает в российских средствах массовой информации отнюдь не доминирующее, но в то же время весьма заметное место. Вот только один пример: за период с сентября 2014 г. по январь 2019 г. на сайте издания «Аргументы и Факты» этой теме было посвящено 24 статьи ${ }^{1}$.

\section{ОПРОКИНУТЫЕ В ПРОШЛОЕ}

Большинство публикаций на тему российско-польских отношений содержит в себе более или менее развернутый экскурс в прошлое. Это вполне естественный результат поиска ответа на вопрос «Как же так получилось?». К сожалению или к счастью, но наша совместная история оставила много пищи для размышлений.

Отношения между двумя славянскими странами длятся уже более тысячи лет и полны неоднозначности. Связано это со многими причинами, среди которых можно выделить географическое положение Польши и России, которые граничат друг с другом, имманентное политическое развитие двух государств, амбиции их правящих кругов, вмешательство в российско-польские отношения третьих сил, стремившихся разыграть «польскую карту» в своих интересах. Как отмечается в одном из российских изданий: «Тысячелетняя история взаимоотношений народов сегодняшней России и Польши хранит в себе массу белых и темных пятен. Были у нас и совместные военные победы, и войны друг против друга, и Вечный мир, и даже жизнь в одном государстве» ${ }^{2}$. Упомянутые здесь белые и темные пятна - это как раз то, что позволяет легко создать контраст, нужный тем или иным политикам и идеологам. Трудно не согласиться с мнением Д. ОфицероваБельского: «Вопрос взаимоотношений русских и поляков исторически непростой. Настолько, что практически любая тема, имеющая отношение к двум народам, может перерасти в ссору, полную взаимных упреков и перечисления грехов» ${ }^{3}$.

При этом в средствах массовой информации России бытует мнение, что в оценке событий прошлого у поляков присутствует идеологическая предвзятость, связанная с историческими комплексами этой страны. У поляков, как считает Д. Офицеров-Бельский, очень развита «способность хранить память о своих страданиях» ${ }^{4}$. По всей видимости, это обостренное восприятие прошлого объясняется тем, что исторически взаимоотношения двух

\footnotetext{
1 Материаль по теме: отношения России и Польщи, http://www.aif.ru/tag/otnoshjenija_rossii_i_polshi (25.01.2019).

2 Реален ли новый «славянский союз» Польши и России?, https://news.rambler.ru/other/41567127-realen-linovyy-slavyanskiy-soyuz-polshi-i-rossii/ (20.01.2019).

3 Д. Офицеров-Бельский, Бесконечный спор: Почему в российско-польских отношениях все так сложно?, https://lenta.ru/articles/2015/02/14/polishrelations2/ (20.01.2019).

${ }^{4}$ Ibidem.
} 
стран сложились так, что наступающей стороной долгое время были поляки. Речь Посполитая в XVI в. являлась одним из крупнейших государств Европы. Ее границы простирались «от моря до моря». Примечательно, что именно она стала историческим идеалом для польской нации и до сих пор идеей возрождения «Польши от моря до моря» в той или иной форме грезят наиболее оголтелые польские националисты.

На период польского превосходства приходится один из наиболее драматичных периодов истории России - Смутное время конца XVI - начала XVII вв. Тогда над страной, ставшей добычей всевозможных авантюристов, местных и иноземных, в том числе польских, нависла угроза потери государственности. И только действия Второго народного ополчения, сформированного в обстановке подъема освободительного движения осенью 1611 г. в Нижнем Новгороде, спасли Россию от распада и порабощения. Собранная народная рать подошла к Москве и освободила столицу от засевших там поляков, что создало условия для возрождения страны. Правда, необходимо отметить, что поляков впустили в Москву сами московские бояре, пригласившие на русский престол польского королевича Владислава. Запланированная уния двух государств вполне могла состояться, если бы не действия короля Сигизмунда III. Но в итоге окончание Смуты, которое для россиян стало актом сохранения национальной независимости, для поляков обернулось «упущенным шансом». В этом контексте учреждение в Российской Федерации в 2005 г. нового государственного праздника, «Дня народного единства», было воспринято частью польской общественности с неприязнью.

Вплоть до конца XVII в., невзирая на многие противоречия, разрушавшие ее изнутри, Речь Посполитая играла весьма заметную роль в Европе. Именно польские полки фактически обратили вспять турецкое нашествие, внеся решающий вклад в разгром османской армии под Веной в 1683 г. Поляки очень гордятся этой победой. Однако уже с началом следующего столетия инициатива в польско-русских отношениях перешла к России, и наступающей стороной стали русские.

Причем потенциал двух стран оставался сопоставимым. «В конце XVII века население Московского царства превышало 10 миллионов человек, что немногим более, чем в соседней Речи Посполитой, где проживали 8 миллионов, а во Франции 19 миллионов. В те времена у соседей-поляков не было и не могло быть комплекса малого народа, которому угрожают с Востока» ${ }^{5}$.

Однако постепенно такой комплекс у поляков стал развиваться, поскольку на фоне расширения границ и все более укрепляющегося абсолютизма России, ее сосед превращался «в совершенно нежизнеспособное государство» с уменьшающейся территорией. «Кризис государственной власти, начавшийся при самом выдающемся из польских королей Яне III Собеском, привел к катастрофическому сжатию, а затем и гибели

\footnotetext{
${ }^{5}$ Ibidem.
} 
польского государства, потерявшего внутренний консенсус» ${ }^{6}$. Гибельным для польской государственности стало сочетание внутренних и внешних факторов - вокруг слабой, раздираемой внутренними противоречиями Польши сформировались сильные абсолютистские державы. Инициатором разделов Речи Посполитой была отнюдь не Россия: «... вполне определенно можно сказать, что инициатива первого раздела принадлежала Австрии, второго - Пруссии, а завершающего третьего - России. Все поровну, а это не детский спор о том, кто первый начал» ${ }^{7}$.

Рассматривая дальнейшие взаимоотношения двух стран, необходимо отметить, что они не сводились к попыткам Польши вернуть свою независимость и ответным репрессивным действиям российских властей. Поляки в период вхождения в состав Российской империи оставили заметный след в истории и культуре России. Можно вспомнить не один десяток выдающихся деятелей, но назовем лишь два имени, оказавшихся участниками поворотных событий - Игнатия Гриневицкого и Феликса Дзержинского. Первый 1 марта 1881 г. бросил роковую бомбу под ноги царюосвободителю Александру II. Император получил смертельные ранения и вскоре скончался. Второй возглавил после прихода к власти в России большевиков такую организацию как ЧК, ставшую «карающим мечом» революции.

Что касается советского периода, то немилосердный ко всему человечеству XX век разбередил многие старые раны в отношениях России и Польши и нанес новые, не заживающие до сих пор.

\section{НЕЗАВЕРШЕННЫЙ XX ВЕК}

Автор одной из статей «Комсомольской правды» заметила: «...впечатление такое, что в XXI веке почти каждое польское правительство решило посчитаться с Россией за все прошлые подлинные и мнимые обиды» ${ }^{8}$. Так как наиболее тяжелые и памятные обиды относятся к предшествующему столетию, их обсуждают чаще всего. В этом смысле $\mathrm{XX}$ век трудно отнести к прошедшему времени.

Основные претензии поляков связаны со следующими событиями:

1. Советско-германские соглашения 1939 г.

2. Катынский расстрел.

3. Варшавское восстание 1944 г.

4. Пребывание Польши в составе т.н. «социалистического лагеря» в послевоенный период.

Вот как данные проблемы интерпретируются в современных российских СМИ:

\footnotetext{
${ }^{6}$ Ibidem.

${ }^{7}$ Ibidem.

${ }^{8}$ Е. Баранова, Россия-Польша: Неужели мы обречены на вечную неприязнь?, https://www.spb.kp.ru/daily/ 26546/3562835/ (20.01.2019).
} 
1. Обстановка в мире после прихода Гитлера к власти в Германии в 1933 г. постоянно накалялась. Нацисты начали проводить политику реваншизма за поражение в Первой мировой войне, откровенно попирая основы Версальско-Вашингтонской системы, определившей устройство Европы после завершения войны. Гаранты этой системы, прежде всего Англия и Франция, спокойно смотрели на происходящее, проводя «политику умиротворения». В 1938 г. состоялся т.н. «мюнхенский сговор», в результате которого Англия и Франция отдавали Гитлеру Судетскую область Чехословакии, но практически они отдавали всю Чехословакию, которая вскоре была оккупирована нацистами. В дележе Чехословакии участвовала и Польша, которой отошла Тешинская область, так что в этой ситуации поляки выступили союзниками немцев.

Правительство СССР в 1930-е гг. старалось проводить политику «коллективной безопасности», стремясь предотвратить агрессивные действия Германии в Европе, но из-за позиции Англии и Франции из этого ничего не вышло. В создавшихся условиях Сталин, боясь оказаться в изоляции, тем более что на востоке у СССР сложились очень напряженные отношения с Японией, и дело доходило до военных конфликтов, пошел на подписание пакта о ненападении с Германией, вошедшего в историю как «пакт МолотоваРиббентропа». Нельзя отрицать, что данное соглашение усилило позиции Германии, но надо понимать, что это была вынужденная мера, и к ней Сталина подтолкнули сомнительные действия Англии и Франции. Когда Гитлер 1 сентября 1939 г. вторгся в Польшу, то эти страны, объявив Германии войну, не предприняли фактически никаких шагов, чтобы спасти поляков, а их войска отсиживались за «линией Мажино». Сама же польская армия, несмотря на отдельные эпизоды героической борьбы, не смогла оказать достойного сопротивления агрессору. К 17 сентября польского государства де-факто не стало, его правительство покинуло страну, после чего Красная Армия вступила на территории Западной Украины и Западной Белоруссии, дойдя до «линии Керзона». Как известно, эта линия была рекомендована 2 декабря 1919 г. Верховным советом Антанты как восточная граница Польши. Поэтому с российской стороны произошедшее вполне может оцениваться так: «По сути, этот шаг был восстановлением признанной мировым сообществом нормы, нарушенной Польшей в ходе советско-польской войны 1919-1921 годов» ${ }^{9}$. Но в польских СМИ на такие факты не обращают внимания, назначая СССР худшим из агрессоров: «В телепередачах больше внимания «достается» не 1 сентября 1939 г., дню вторжения Германии в Польшу, и зверским бомбардировкам Варшавы, a 17 сентября, когда Красная армия взяла под контроль Западную Белоруссию и Западную Украину» 10 .

\footnotetext{
${ }^{9}$ А. Сидорчик, История большой лжи. Миф и правда о Варшавском восстании, http://www.aif.ru/society/ history/istoriya_bolshoy_lzhi_mif_i_pravda_o_varshavskom_vosstanii (20.01.2019).

${ }^{10}$ Г. Зотов, Печаль вариавянки. Почему в Польше не рады освобождению от фашизма, http://www.aif.ru/ society/history/pechal_varshavyanki_pochemu_v_polshe_ne_rady_osvobozhdeniyu_ot_fashizma (20.01.2019).
} 
2. «Катынский расстрел»- массовый расстрел польских граждан, в основном офицеров польской армии, сотрудников полиции и Корпуса охраны границы, а также мирных обывателей из числа жителей восточных польских регионов. Сам термин «Катынский расстрел» сначала использовался в отношении расстрела польских офицеров в Катынском лесу недалеко от села Катынь в Смоленской области. Позже этот термин стали употреблять также по отношению к проведенным в апреле-мае 1940 г. расстрелам польских граждан, содержавшихся в разных лагерях и тюрьмах НКВД СССР. Советский Союз долгое время отрицал свою причастность к «Катынскому расстрелу», но в 1990 г. официально признал ответственность за эту трагедию. В сентябре 1990 г. Главная военная прокуратура СССР начала расследование катынского дела, которое продолжалось в России до 2004 г. В ходе расследования польская сторона выдвинула версию о геноциде польского народа, но она была отвергнута российской стороной. Польской стороне была передана значительная часть архивных материалов по делу, но другая часть засекречена и по-прежнему находится в Москве.

26 ноября 2010 г. Госдумой РФ было принято заявление «О Катынской трагедии и ее жертвах», признававшее и осуждавшее массовый расстрел польских граждан в Катыни, говорившее о том, что это было сделано согласно прямому указанию Сталина и других советских руководителей того периода. В апреле 2012 г. Европейский суд по правам человека классифицировал «Катынский расстрел» как военное преступление. В настоящее время на месте трагических событий открыт Государственный мемориальный комплекс «Катынь», который состоит из двух частей: на одной захоронены жители Смоленщины, ставшие жертвами политических репрессий, а на второй размещено военное кладбище расстрелянных польских офицеров.

Казалось бы, на этом можно поставить точку в деле о «Катынском расстреле», но в Польше по-прежнему есть круги, которые используют эту трагедию для обострения отношений с Россией. В российских СМИ такую позицию осуждают и даже выдвигают предложения, как навсегда решить вопрос о катынской трагедии. Например, научный сотрудник Института славяноведения РАН Вадим Волобуев считает, что необходимо рассекретить все документы по Катыни и передать их Польше. Далее он говорит: «Я не разделяю мнение некоторых поляков о том, что это был акт геноцида, это было преступление против человечества. Нужно решить этот вопрос в Гаагском трибунале, открыв все документы. Поляки, утверждающие, что это был акт геноцида, суд проиграют, нам это будет выгодно» ${ }^{11}$.

3. Проблема Варшавского восстания 1944 г. заключается в том, что в оккупированной немцами Польше было несколько групп Сопротивления, придерживающихся разных взглядов: Армия Людова, созданная коммунистами и ориентировавшаяся на Советский Союз, и Армия Крайова, ориентировавшаяся на польское эмиграционное правительство

\footnotetext{
${ }^{11}$ Е. Баранова, Россия-Польша: Неужели мы обречены на вечную неприязнь?, https://www.spb.kp.ru/daily/ 26546/3562835/ (20.01.2019).
} 
в Лондоне. По мере приближения советских войск к Польше лондонское правительство, боявшееся остаться не у дел, разработало план «Буря». Смысл этого плана заключался в том, чтобы по мере отступления немецких войск Армия Крайова захватывала некоторые населенные пункты и создавала там органы власти под эгидой лондонского правительства, показывая тем самым его значимость и влияние. Важнейшей частью этой операции должно было стать восстание в Варшаве. Силы Армии Крайовой накануне подхода советских войск должны были освободить столицу от немцев и создать там свои органы власти, продемонстрировав СССР, что в стране якобы восстановлена власть эмиграционного правительства. Естественно, командование Красной Армии не было об этом извещено. Надеясь на быстрый подход наступающих советских войск, генерал Тадеуш Коморовский начал восстание 1 августа 1944 г. Очень скоро стало ясно, что это авантюра. Оказалось, что гитлеровцы узнали о готовящемся восстании и сумели ввести в Варшаву дополнительные силы. Восставшим не удалось захватить стратегические объекты, и по сути, вместо мощного восстания возникли лишь разрозненные очаги сопротивления. Советские войска, ослабленные предыдущим наступлением, не смогли прорваться к Варшаве и помочь восставшим. 2 октября 1944 г. генерал Коморовский подписал капитуляцию. Восстание было подавлено, столица Польши разрушена. Стремясь оправдаться и обвинить во всем произошедшем Советский Союз, польское эмиграционное правительство стало распространять миф о «предательстве варшавского восстания Сталиным». Этот миф оказался очень живуч и в настоящее время активно используется как в Польше, так и на Западе. Совсем недавно, выступая в Варшаве, президент Соединенных Штатов Трамп в своей речи прямо обвинил Красную Армию в поражении восстания: «Советские вооруженные силы остановились и ждали, смотрели, как нацисты уничтожали все живое и пытались подавить саму волю к жизни» ${ }^{12}$.

На этом фоне российские журналисты пытаются опровергнуть миф о «предательстве варшавского восстания». Например, Андрей Сидорчик в своей статье «История большой лжи. Миф и правда о Варшавском восстании» отмечает: «Документы свидетельствуют, что Красная Армия, не знавшая о восстании, не могла учитывать его в своих планах, и физически не готова была ему помочь» ${ }^{13}$. Далее он приводит слова маршала Советского Союза Константина Рокоссовского, поляка по национальности, который в интервью иностранным журналистам в августе 1944 г. так охарактеризовал сложившуюся ситуацию: «Командование Армии Крайовой совершило страшную ошибку», и дал такую оценку происходящего: «... речь идет о политической авантюре, и авантюра эта будет стоить Польше сотни тысяч жизней. Это ужасающая трагедия, и сейчас всю вину за нее пытаются переложить на нас. Мне больно думать о тысячах и тысячах людей, погибших в нашей борьбе за освобождение Польши. Неужели же вы считаете, что мы не взяли бы Варшаву,

\footnotetext{
${ }^{12}$ А. Сидорчик, История большой лжи. Миф и правда о Варшавском восстании, http://www.aif.ru/society/ history/istoriya_bolshoy_lzhi_mif_i_pravda_o_varshavskom_vosstanii (20.01.2019).

${ }^{13}$ Ibidem.
} 
если бы были в состоянии это сделать? Сама мысль о том, будто мы в некотором смысле боимся Армии Крайовой, нелепа до идиотизма» ${ }^{14}$.

Другой автор, Георгий Зотов, пишет о том, что в сегодняшней Польше в крахе Варшавского восстания принято винить «плохих русских», которые не пришли на помощь и именно они повинны в разрушении 70\% польской столицы и гибели 200 тысяч мирных жителей. А то, что «восстание было поднято без предупреждения и имело цель срочно провозгласить в Варшаве власть эмигрантского правительства перед приходом Красной армии» старательно игнорируется ${ }^{15}$.

4. В настоящее время в Польше идет явный пересмотр событий Второй Мировой войны и послевоенного периода. Как отмечает Г. Зотов: «За последние годы и в школьных учебниках, и на уровне парламента и правительства Польши неоднократно высказывалось: дескать, ничего хорошего освобождение от фашизма польскому народу не принесло, «просто одна тирания сменилась на другую» ${ }^{16}$. Причиной всех бед Польши теперь назначены русские. А ведь в годы войны Польша потеряла свою государственность, на ее территории появились немецкие переселенцы, осваивающие «новое жизненное пространство» для Германии. Фактически польской нации в перспективе грозило полное уничтожение. За время нацистской оккупации Польша потеряла 21,4\% своего населения. На польской территории были расположены наиболее одиозные концентрационные лагеря. Поляки считались «унтерменшами» - людьми второго сорта. Нельзя не признать, что после освобождения в Польше был установлен режим, который не нравился значительной части населения, но при этом поляков никто не уничтожал как нацию, страна стала большим независимым государством, пусть и под некоторым влиянием «большого брата» из Москвы. Именно СССР оказал помощь в восстановлении республики из руин, однако теперь освобождение Польши от нацистов стали именовать «оккупацией». Объясняется это тем, что теперь «у Польши новый «большой брат» - США - и новый враг - Россия. А о врагах следует говорить плохо» ${ }^{17}$.

Надо сказать, российская сторона не остается в долгу, выдвигая в адрес Польши встречные упреки. Среди таковых обычно фигурируют:

1. Трагическая судьба красноармейцев, попавших в польский плен в период войны с Польшей 1919-1921 гг.

2. Цена освобождения советскими войсками территории Польши от немецких оккупантов.

1. В период советско-польской войны 1919-1921 гг. в польский плен попало большое число красноармейцев (точное их число не установлено до сих пор). Пленные содержались в ужасных условиях в лагере, находившемся в местечке Тухоль. Из-за условий

\footnotetext{
${ }^{14}$ Ibidem.

${ }^{15}$ Г. Зотов, Печаль варшавянки. Почему в Польше не рады освобождению от фашизма, http://www.aif.ru/ society/history/pechal_varshavyanki_pochemu_v_polshe_ne_rady_osvobozhdeniyu_ot_fashizma (20.01.2019).

${ }^{16}$ Ibidem.

${ }^{17}$ Ibidem.
} 
содержания, действий охраны и начальства лагеря большинство из них умерло. Спор между Россией и Польшей о количестве погибших в лагере не завершен до сих пор. По данным Адольфа Иоффе, главы советской делегации на рижских мирных переговорах 1921 г., речь идет о приблизительно 60 тысячах, впрочем, в прессе фигурируют и более высокие цифры ${ }^{18}$. Министр культуры Владимир Мединский выступил с инициативой сбора средств на памятник красноармейцам, погибшим в польских концлагерях в 19201921 гг. Польская сторона ответила отказом и возмутилась тому, что упомянутый лагерь для военнопленных красноармейцев был назван концлагерем. Польский МИД выразил претензии, заявив, что с 1918 по 1939 г. в Польше концлагерей не существовало. Однако, как называть лагерь, в котором пленные содержались в ужасных условиях и подвергались издевательствам? Дмитрий Офицеров-Бельский в своей статье «Мертвые без погребения», ссылаясь на слова полпреда РСФСР в Польше от 6 января 1922 г., пишет: «Арестованных ежедневно выгоняют на улицу и вместо прогулок обессиленных людей заставляют под команду бегать, приказывая падать в грязь и снова подниматься. Если пленные отказываются ложиться в грязь или если кто-нибудь из них, исполнив приказание, не может подняться, обессиленный тяжелыми условиями своего содержания, то их избивают прикладами» ${ }^{19}$.

2. В ответ на переоценку поляками освобождения их страны советскими войсками от немецких оккупантов, российские СМИ акцентируют внимание на том, какую цену пришлось заплатить Красной Армии за освобождение польской земли. Согласно официальным данным, при этом погибло 650 тысяч советских солдат и офицеров. Высказывания поляков о том, что немецкая оккупация сменилась советской, весьма негативно воспринимаются в России и серьезно влияют на восприятие образа Польши в глазах россиян. «Бестактно сравнивать фашистский режим с тем, что было после войны. Фашисты хотели истребить поляков как народ, от этой ужасной участи их спасла наша армия» $^{20}$.

\section{НОВЫЕ ПЛОДЫ СТАРОЙ НЕПРИЯЗНИ}

К многочисленным взаимным претензиям, доставшимся в наследие от прошлых времен, за последние годы, к сожалению, добавились новые. Хотя, если присмотреться, в каждом из новых казусов история проглядывает явственно. Связаны они со следующими событиями и процессами:

1. Снос советских памятников на территории Польши.

2. Гибель польской делегации в авиакатастрофе под Смоленском.

\footnotetext{
18 Д. Офицеров-Бельский, Мертвые без погребения. Ответ автора «Ленты.ру» посольству Польши в Москве, https://lenta.ru/articles/2015/02/10/answer/ (20.01.2019).

${ }^{19}$ Ibidem.

${ }^{20}$ Е. Баранова, Россия-Польша: Неужели мы обречены на вечную неприязнь?, https://www.spb.kp.ru/daily/ 26546/3562835/. (20.01.2019).
} 
3. Украинский вопрос.

1. Снос памятников советским воинам-освободителям на территории современной Польши относится к числу наиболее болезненных тем. В период с 1997 г. по 2010 г. количество памятников, увековечивающих память советских военачальников и солдат, сократилось на одну треть - с 561 до 300 монументов. Подобная практика продолжалась и в последующие годы, существует она и в настоящее время. Возглавляет движение за демонтаж памятников партия «Право и справедливость», для которой борьба с советским наследием стала одним из «ключевых элементов политической идеологии». В российских СМИ данной проблеме уделяется большое внимание. Среди статей на эту тему можно выделить статью «Войны памяти продолжаются», в которой дается взвешенный анализ происходящего. В частности, в статье отмечается, что отнюдь не все поляки рьяно выступают за снос памятников советским воинам-освободителям. По поводу сноса некоторых памятников в обществе даже возникали острые дискуссии и настоящие скандалы, как, например, при демонтаже памятника генералу Ивану Черняховскому. Как отмечается в статье: «Разумеется, каждое подобное обострение вызывало как острое внутреннее противостояние в польском обществе, так и приводило к ухудшению отношений с Россией, для которой тема Великой Отечественной войны и роли советских солдат в освобождении Европы от немецкой оккупации является чрезвычайно болезненной. Российский МИД неоднократно выступал с официальными протестами против возможного демонтажа памятников советским командирам и красноармейцам, видя в этом попытки пересмотра итогов войны» ${ }^{21}$.

2. Катастрофа польского самолета Ту-154, в котором летела польская делегация во главе с президентом Лехом Качиньским, произошла под Смоленском 10 апреля 2010 г. На борту находилось 96 человек - 88 пассажиров и 8 членов экипажа. Все находящиеся в самолете, в том числе президент Польши Лех Качиньский и его супруга Мария, погибли. Погибшие направлялись в Россию с частным визитом по случаю семидесятой годовщины «Катынского расстрела». Расследование Межгосударственного авиационного комитета установило, что причиной крушения стало столкновение с деревьями при заходе на посадку в условиях плохой видимости. «Через 15 месяцев после катастрофы комиссия Международного авиационного комитета (МАК) представила доклад о причинах трагедии, в котором указывалось на комплексность обстоятельств, приведших к катастрофе. Однако основной причиной названы ошибочные действия экипажа» ${ }^{22}$.

Польские следователи и эксперты много раз приезжали в Россию для работы с вещественными доказательствами, и, казалось бы, причины авиакатастрофы были выяснены. Однако после прихода к власти в Польше партии «Право и справедливость»,

\footnotetext{
${ }^{21}$ Войнь памяти продолжаются, http://ru.rospol.org/wojna-pomnikow.html (20.01.2019).

22 О. Ефимкина, Следствие по кругу. «Взрьвв в самолете Качиньского» снова не подтверждается, http://www.aif.ru/politics/world/sledstvie_po_krugu_vzryv_v_samolete_kachinskogo_snova_ne_podtverzhdaets ya (20.01.2019).
} 
которую возглавил брат погибшего Леха Качиньского - Ярослав, тема смоленской трагедии стала сильно политизироваться. Начали выдвигаться самые различные версии гибели самолета, посыпались обвинения в адрес Москвы, причем поведение польской стороны, и особенно Ярослава Качиньского, стало приобретать характер какого-то гротеска и трагикомедии, что и было отмечено в средствах массовой информации России и отнюдь не улучшило образ Польши в глазах россиян. Как считает Андрей Сидорчук, спекуляции вокруг «самолета президента» в Польше завершатся не раньше, чем в Варшаве сменится власть ${ }^{23}$.

3. События 2014 г. на Украине спровоцировали масштабный внешнеполитический кризис. Одним из его звеньев стало дальнейшее ухудшение польско-российских отношений. Приведем несколько выдержек из статей, посвященных данной проблеме в российской прессе.

Олег Неменский уже летом 2014 г. констатировал: «...проводившаяся правительством Дональда Туска на протяжении шести с лишним лет политика «нормализации отношений» с Россией фактически отменена. Польша возвращается к конфронтационной линии. События весны 2014 г. на Украине и их восприятие внутри Польши не позволяют продолжать прежнюю политику» ${ }^{24}$. В статье «Россия-Польша: неужели мы обречены на вечную неприязнь?», опубликованной в 2016 г. в газете «Комсомольская правда», Екатерина Баранова отмечает, что в украинском вопросе «Варшава целиком приняла сторону «сил майдана», пришедших к власти через госпереворот» ${ }^{25}$. Подобную точку зрения разделяют практически все авторы статей, посвященных современным российско-польским отношениям.

Еще одно важное обстоятельство: воссоединение Крыма с Россией воскресило в Польше призраков прошлого, возродило былой страх перед «угрозой с Востока». О.Неменский так описывает реакцию польского общества на этот шаг России: «Воссоединение Крыма с Россией вызвало всеобщую истерию в польских СМИ. Большинство изданий вышло с кричащими заголовками вроде «Сегодня Украина - завтра Польша!» Надо отметить, что это событие действительно воспринимается многими поляками именно как первый шаг против Польши...» ${ }^{26}$.

Впрочем, в российских публикациях распространено мнение, что опасение «угрозы с Востока» у современных поляков не столько возникает из-за аналогий с прошлым, сколько формируется современными политиками в своих целях. На эту проблему обращает внимание Г. Зотов: «И телевидение, и газеты, и политики любых мастей

\footnotetext{
${ }^{23}$ А. Сидорчик, Казус Качиньского. Все о катастрофе Ту-154 под Смоленском без мифов, http://www.aif.ru/ society/history/kazus_kachinskogo_vse_o_katastrofe_tu-154_pod_smolenskom_bez_mifov (20.01.2019).

24 О. Неменский, Российско-польские отномения: конеи «нормализаиии», https://regnum.ru/news/ 1829783.html (20.01.2019).

${ }^{25}$ Е. Баранова, Россия-Польша: Неужели мы обречены на вечную неприязнь?, https://www.spb.kp.ru/daily/ 26546/3562835/ (20.01.2019).

26 О. Неменский, Российско-польские отношения: конеи «нормализаиии», https://regnum.ru/news/18297 83.html (20.01.2019).
} 
последние 25 лет целыми сутками мусолят одно и то же: дескать, Россия спит и видит оккупацию Варшавы. На вопрос, зачем это русским, хором возмущаются: «Как зачем? Вы что, русских не знаете?!» ${ }^{27}$.

Несомненно, польское правительство «стало активно использовать украинский кризис для нагнетания атмосферы страха перед угрозой со стороны России. И эта пропаганда принесла свои плоды». При этом подчеркивается, что «Начиная с февраля 2014 г. политики «Гражданской платформы» стали соревноваться с оппозиционерами из «Права и Справедливости» в резкости заявлений в адрес России» ${ }^{28}$. Фактически это означает, что две ведущие партии Польши стали проводить русофобскую по своей сути политику.

Одновременно в российских СМИ возросшую антироссийскую направленность польской политики связывают с тем, что из-за украинских событий ухудшились отношения России и США. Действительно, во взаимодействии России и Польши прослеживается определенная закономерность - отношения двух славянских стран нормализуются, когда улучшаются российско-американские отношения, и наоборот. «Разрядка, которую обыкновенно связывают с гибелью Леха Качиньского и конструктивной поначалу политикой Туска, на самом деле была связана с«перезагрузкой» в российско-американских отношениях. Закончилась перезагрузка, завершилась и нормализация отношений с Варшавой» ${ }^{29}$. Так что состояние российско-польских отношений фактически зависит от США, а Вашингтон использует «польскую карту» в своих интересах не только применительно к России, но и к ЕС. Кампания по противодействию «угрозе с Востока» тоже осуществляется в интересах НАТО и прежде всего США, используется как повод для размещения войск на польской территории с целью оказания давления на Россию.

Российские публицисты сомневаются в целесообразности такой политики западного соседа. Касается это и усиления военного присутствия НАТО на польской земле, и участия поляков в антироссийских санкциях. Например, Александр Шторм пишет, что Польша проводит антироссийскую политику в ущерб своим экономическим интересам, выступая в авангарде тех, кто требует экономических санкций против России: «Официальная Варшава возвела свои антироссийские фобии в ранг государственной политики. По вопросу экономических санкций против России Польша не ограничивается жесткой позицией на международной арене - к примеру, при каждом удобном случае требуя их ужесточения на форуме Евросоюза» ${ }^{30}$.

27 Г. Зотов, Польская паника. Варшава измучила себя страхом перед «угрозой с Востока», http://www.aif.ru/politics/world/polskaya_panika_varshava_izmuchila_sebya_strahom_pered_ugrozoy_s_vostok a (20.01.2019).

28 О. Неменский, Российско-польские отношения: конец «нормализации», https://regnum.ru/news/18297 83.html (20.01.2019).

${ }^{29}$ Г. Мирзаян, Конфликт с Россией как попутный ветер, http://expert.ru/2016/02/9/polsha/ (20.01.2019).

30 А. Шторм, Польские санкиии: от экспорта в Россию к импорту из Китая, https://eadaily.com/ru/news/ 2017/12/19/polskie-sankcii-ot-eksporta-v-rossiyu-k-importu-iz-kitaya (20.01.2019). 
Подводя итоги обзора публикаций в современных российских СМИ, можно сделать вывод о том, что образ Польши в них складывается преимущественно отрицательный. Констатируется напряженность в российско-польских отношениях, ответственность за это возлагается на Польшу. Вместе с тем, российские журналисты неоднократно подчеркивали, что виноваты в этом польские правящие круги, а не все поляки. Именно польское правительство, идя в фарватере политики США, стремится нагнетать истерию вокруг пресловутой «угрозы с Востока», для того чтобы разместить войска НАТО как можно ближе к российской границе. Несмотря на это, кое-кем из авторов выражается надежда на улучшение российско-польских отношений в будущем, поскольку это в интересах как России, так и Польши. Но пока заметных позитивных результатов на этом пути нет, наоборот, возникает ощущение, что отношения лишь обостряются.

\section{ОПРОС СТУДЕНТОВ СПБГТИ(ТУ) ОБ ОТНОШЕНИИ К ПОЛЬШЕ И ЕГО РЕЗУЛЬТАТЫ}

Теперь, используя результаты проведенного нами опроса, попытаемся оценить, насколько формируемая в СМИ картина российско-польских отношений воспринимается представителями российской молодежи.

Опрос в письменной форме проводился среди первокурсников трех факультетов СПбГТИ(ТУ) 2018 года поступления. Всего было опрошено 220 человек, однако 13 участников отсеяли по возрастному (старше 18 лет) или политико-географическому (граждане ближнего зарубежья) показателю. Соответственно, учитывались данные 207 анкет. Возраст респондентов - 17-18 лет. Не будет преувеличением сказать, что в географическом отношении опрошенные студенты представляли всю Россию (от Пскова до Анадыря, от Мурманска до Владикавказа, всего около 90 населенных пунктов), хотя жители Санкт-Петербурга все-таки преобладали (32\%).

Опрос был организован в самом начале учебного года, поэтому никакого влияния вузовских учебных дисциплин (истории России в частности) опрашиваемые еще не испытывали, опираясь в своих ответах прежде всего на сведения из школьной программы и обыденное знание, тесно связанное с существующими в обществе стереотипами и информацией, тиражируемой СМИ. Собственный опыт взаимодействия респондентов с поляками и польской культурой прослеживался лишь в единичных случаях.

Время опроса было ограничено приблизительно четвертью часа, следовательно, возможности для долгих раздумий у студентов не имелось.

Целью опроса было определение степени осведомленности вчерашних школьников о состоянии польско-российских отношений, выявление существующих в их среде стереотипных представлений о польской истории и культуре, а также оценка силы влияния российских СМИ на отношение российских студентов к Польше.

Опрашиваемым были предложены четыре вопроса: 
1. «Как бы Вы охарактеризовали позицию Польши по отношению к России в настоящее время?» Варианты ответа: «партнер» / «соперник» / «нейтральная страна» / «другое» (в последнем случае требовалось дать свою версию ответа).

2. «Какие ассоциации возникают у Вас при упоминании поляков / Польши?» В ответе нужно было самостоятельно указать до 5 ассоциаций.

3. «Вы бы согласились жить и работать в Польше на постоянной основе?» Варианты ответа: «да» / «нет» / «не знаю».

4. «Каковы, по Вашему мнению, главные сходства и различия между Россией и Польшей?» Ответ предстояло сформулировать самостоятельно, назвав 3 сходства и 3 различия.

При ответе на первый вопрос результаты распределились следующим образом:

- «Польша - партнер» - 9\%;

- «Польша - соперник» - 19\%;

- «Польша - нейтральная страна» $-59 \%$;

- «другое»-13\%.

В пункте «другое» (26 ответов) наблюдались попытки найти более точное определение для соперничества («противник», «скрытый соперник», «недоброжелатель» и т.п. - всего 9 ответов), отказ от ответа («не знаю», «не интересуюсь» - в 8 случаях) и попытки ввести промежуточные звенья в предложенной схеме «партнер - нейтральная страна - соперник» («между нейтральной и соперником», «народ преимущественно нейтральный, политика власти враждебная» и т.п. -8 ответов). В связи с темой нашей статьи можно выделить один из ответов, согласно которому Польша «выставляется в СМИ как соперник», хотя какой-либо собственной оценкой это наблюдение респондент не сопроводил.

Если сравнивать полученные по этому вопросу анкеты показатели с результатами всероссийского социологического мониторинга ВЦИОМ «Российско-польские отношения» 2012-2014 гг. (по нему преимущественное дружелюбие польского государства/простых поляков к России/русским в 2012 г. отмечали 40\%/39\% респондентов, в $2014-20 \% / 36 \%$, недружелюбие польского государства/простых поляков в 2012 г. - 47\%/52\%, в 2014 $66 \% / 48 \%)^{31}$, то в целом можно отметить избегание студентами крайних позиций и охотное использование нейтральной оценки. Скорее всего, причиной этого является не повышенная толерантность молодых людей, а малая их осведомленность о предмете опроса. То есть выбор ответа «нейтральная страна» свидетельствует об отсутствии какого-либо отношения к проблеме, игнорировании самого существования этой проблемы, нежелании решать дилемму. Участникам опроса ВЦИОМ нейтральный выбор был недоступен, поэтому и итоговая картина получилась более определенной.

В ответах на второй вопрос среди ассоциаций, возникших у студентов Технологического института в связи с Польшей и поляками, явственно преобладают

\footnotetext{
31 Российско-польские отношения: сочиологический мониторинг 2012-2014, M., 2015, https://wciom.ru/
} filadmin/file/reports_conferences/2015/2015-03-06-roosia-polsha.pdf (20.01.2019). 
ассоциации географические, лингвистические, исторические, связанные с польской культурой. Современные российско-польские противоречия оказываются на заднем плане.

Рейтинг географических ассоциаций возглавляют польские столицы (при подавляющем преимуществе Варшавы) - суммарно они содержатся в 22\% анкет. Кроме того, Польша характеризуется как часть географической Европы (14\%), как славянская/западнославянская страна (5\%), как балтийская страна (4\%), как сосед России (2\%), причем последнее мнение уравновешено ответами «сосед Германии» и «сосед Чехии». Ассоциации, связанные с климатом и ландшафтом Польши, указаны в 4\% анкет.

О языке как важной особенности поляков вспомнило $12 \%$ респондентов, причем большинство из них не забыло указать на обилие шипящих в польской речи.

Среди исторических ассоциаций безоговорочно лидирует тема Второй Мировой войны - о ней вспомнили 14\% опрошенных. Из них пятая часть посчитала нужным назвать советско-германские соглашения 1939 г., другая пятая часть - Холокост и Освенцим. На втором месте в этом тематическом блоке оказывается Речь Посполитая (присутствует в 5\% анкет), третье делят события русской Смуты и разделов Польши (по 3\% в каждом случае). Далее идет факт принадлежности Польши к социалистическому лагерю (2\%), а все иные исторические ассоциации («Ливонская война», «шляхта», «крылатые гусары», «Царство Польское», «советско-польская война», «Солидарность») единичны. Добавим, что ни одна историческая личность названа не была.

Культура Польши у опрошенных ассоциировалась с польской кухней и продуктами питания (16\%), со средневековой архитектурой польских городов (13\%), музыкой и танцами (11\%), государственной символикой - гербом и флагом (5\%), туристическими возможностями (5\%), футболом (4\%), католицизмом (3\%), компьютерными играми $(2 \%)$. Здесь же (и только здесь) прозвучали имена известных юным россиянам польских деятелей - Шопена (9 упоминаний), Роберта Левандовского (7), Анджея Сапковского (5), Коперника (1), Януша Вишневского (1).

Тема нынешних российско-польских взаимоотношений, хотя и дала о себе знать в этом вопросе анкеты, по насыщенности ответами уступает предыдущим. К ней посчитали нужным вернуться те, кто негативно оценивает сложившуюся между двумя странами ситуацию. Напряженность отношений, а также недружелюбие польской стороны отметили $11 \%$ опрошенных (напомним, что в первом вопросе Польшу как соперника указали 19\% респондентов). В единичных случаях (1-2 анкеты) упомянуты основные «болевые точки» отношений - Катынь, снос памятников советским солдатам, авиакатастрофа под Смоленском, политика правых польских партий, несамостоятельность польского внешнеполитического курса. Противовес подобным мнениям составляют 3\% респондентов, которые оценивают поляков как хороших людей. Еще 7-8\% рассматривают Польшу как привлекательную в социально-экономическом отношении страну. Наконец, отметим напрямую касающийся нашей проблемы единственный случай отождествления польской темы с продукцией российских СМИ - «новостями по 1-му каналу». 
Существенный процент опрошенных (15\%) не смог указать ни одной ассоциации. Впрочем, по сравнению с уже упоминавшимся мониторингом ВЦИОМ, когда 43\% респондентов затруднились ответить, какие ассоциации вызывает Польша ${ }^{32}$, это не худший результат.

В третьем вопросе, о готовности жить и работать в Республике Польше, преобладающим стал отрицательный ответ (43\% анкет). Следом идет «не знаю» (36\%), и лишь одна пятая часть респондентов (21\%) ответила положительно. Не ставя знака равенства между первым и третьим вопросами (прямой связи между отношением к стране и желанием в ней работать все же нет), заметим, что в последнем ответы определеннее.

Из ответов на четвертый вопрос сложилась весьма противоречивая картина. В большинстве случаев одни и те же характеристики были указаны как среди сходств русских и поляков, так и среди различий. В связи с этим позволим себе обобщение, собрав соответствующие ответы в сравнительно крупные блоки и разместив суммарные результаты по каждому из них в таблице.

\begin{tabular}{|l|c|c|}
\hline \multicolumn{1}{|c|}{ Черта } & $\begin{array}{c}\text { Оценивают как } \\
\text { сходство }\end{array}$ & $\begin{array}{c}\text { Оценивают } \\
\text { как различие }\end{array}$ \\
\hline Этническое происхождение & $20 \%$ & $1 \%$ \\
\hline Язык & $19 \%$ & $20 \%$ \\
\hline История & $12 \%$ & $3 \%$ \\
\hline Географическое положение и природные условия & $11 \%$ & $5 \%$ \\
\hline Менталитет & $11 \%$ & $26 \%$ \\
\hline Культура (быт, фольклор, религия и т.д.) & $9 \%$ & $19 \%$ \\
\hline Политическое устройство и внутриполитическая ситуация & $9 \%$ & $12 \%$ \\
\hline Экономика (характер развития, цели, проблемы) & $6 \%$ & $17 \%$ \\
\hline Размер страны и место на международной арене & - & $24 \%$ \\
\hline $\begin{array}{l}\text { Внешнеполитическая ориентация (отношение с США, } \\
\text { членство в ЕС, членство в НАТО) }\end{array}$ & - & $16 \%$ \\
\hline «Все мы люди» & $4 \%$ & - \\
\hline «Поляки негативно относятся к русским» & - & $2 \%$ \\
\hline & & $20 \%$ \\
\hline Без ответа & $26 \%$ & \\
\hline
\end{tabular}

Таблица 1. Сходства и различия между Россией и Польшей согласно результатам опроса

Процентные соотношения позволяют отнести к числу того, что представляется респондентам сходствами русских и поляков, происхождение от единого славянского корня, близкий исторический путь и географическое положение. К различиям: менталитет, культурную жизнь в целом, экономику, внешнюю политику. Неопределеннопротиворечивым выглядит мнение по поводу языка и политического устройства. Подчеркнем, что только сходство происхождения русских и поляков и отличие внешнеполитической роли России и Польши показались бесспорными для всей группы

\footnotetext{
${ }^{32}$ Ibidem.
} 
опрошенных, в остальных случаях имеет место разделение мнений в соотношении от 25 против 75 до 50 на 50.

Если, исходя из этой таблицы, выводить итоговую стереотипную формулу, то поляк - это человек общего с русскими происхождения, живущий в соседней стране, разделившей исторический путь с Россией, но ориентирующейся на взаимодействие с Западом, говорящий на похожем, но непонятном языке, по образу мыслей и образу жизни весьма далекий от россиян. В общем, перед нами довольно типичный стереотип, который, по замечанию Януша Тазбира, представляет собой «как бы «знания в таблетке», что весьма существенно в эпоху, когда люди за недостатком времени охотно прибегают к упрощениям. Он потрафляет нашей лени, поскольку апеллирует к имеющимся знаниям, которые приобретены сравнительно легко» ${ }^{33}$. О поверхностности знаний респондентов на польскую тему свидетельствуют конкретные (точнее говоря - малоконкретные) ответы на четвертый вопрос и ответы на вопрос об ассоциациях.

Однако в нашем случае важна не столько информативность стереотипа, сколько его эмоциональная окрашенность, оценочная направленность, a также его связь с информацией, закладываемой в общество СМИ. И на этот счет можно сделать следующие - предварительные и осторожные (учитывая ограниченный масштаб проведенного опроса) выводы:

1. Сильных стереотипов, формирующих отчетливую оценку и эмоциональное восприятие поляков, у опрошенной группы студентов в целом не наблюдается. Преобладает нейтральное отношение при недостатке знания о предмете. Или даже отсутствие какого-либо отношения, индифферентность, безразличие.

2. Силу воздействия российских масс-медиа на мнение студенческой молодежи о польско-российских отношениях нельзя признать выдающейся и даже существенной. Сюжеты, муссируемые в СМИ, оказались в поле зрения явного меньшинства опрошенных, а констатацию опрошенными того, что Россия - большая и играет значительную роль в мировой политике или что Польша - часть западного мира, едва ли следует относить к числу политизированных сюжетов. «Кремлевская пропаганда», о которой так любят рассуждать некоторые зарубежные и российские авторы, в случае проведенного опроса никак себя не проявляет. Говорить о каком-либо следе пропагандистского нагнетания не приходится. Это не значит, что «пропагандистская машина» в Российской Федерации вообще бездействует, однако ее влияние на молодежь - под большим вопросом.

\section{ЗАКЛЮЧЕНИЕ}

Оценивать наблюдаемую по итогам опроса ситуацию можно двояко. Неплохо то, что у российских студентов нет выраженной полонофобии, что отсутствие готовой,

\footnotetext{
${ }^{33}$ В. Хорев, Имагология и изучение русско-польских литературных связей, [в:] Поляки и русские в глазах друг друга, ред. В. Хорев, М., 2000, с. 23.
} 
навязанной кем-то модели отношений оставляет свободу личного выбора. Но сам этот выбор невозможен или предельно случаен без полноценного знакомства с польской действительностью, польской культурой, историей, без понимания их длительных и разнообразных связей с Россией. Возможности и желание для такого знакомства имеются лишь у явного меньшинства молодых россиян, даже если речь идет об учащихся высших учебных заведений. А наблюдаемое ныне осложнение российско-польских отношений устранению общей неосведомленности друг о друге не способствует. Остающаяся в результате «tabula rasa» хранит в себе потенциальную возможность быстрого ее заполнения упрощенной информацией определенной пропагандистской направленности. Если с этой задачей не справляются современные российские СМИ, это не значит, что она неразрешима в принципе. Об этом не стоит забывать, в том числе и польской стороне, когда она предпринимает ту или иную недружественную акцию в адрес России или разрывает установленные ранее связи. Старательное создание образа вымышленного врага может породить врага настоящего, от чего ни одна из стран не выиграет.

\section{ЛИТЕРАТУРА}

Баранова Екатерина. 2016. Россия-Польша: Неужели мы обречены на вечную неприязнь? B https://www.spb.kp.ru/daily/26546/3562835/ [Baranova Ekaterina. 2016. RossiyaPol'sha: Neuzheli my obrecheny na vechnuyu nepriyazn'? Vhttps:/www.spb.kp.ru/ daily/26546/3562835/].

Войны памяти продолжаются. 2017. В http://ru.rospol.org/wojna-pomnikow.html [Vojny pamyati prodolzhayutsya. 2017. V http://ru.rospol.org/wojna-pomnikow.html].

Ефимкина Ольга. 2018. Следствие по кругу. «Взрыв в самолете Качиньского» снова не подтверждается B http://www.aif.ru/politics/world/sledstvie_po_krugu_vzryv_v_samolete _kachinskogo_snova_ne_podtverzhdaetsya [Efimkina Ol'ga. 2018. Sledstvie po krugu. „Vzryv w samolyote Kachinskogo" snova ne podtverzhdaetsya V http://www.aif.ru/politics/world/sledstvie_po_krugu_vzryv_v_samolete_kachinskogo_sn ova_ne_podtverzhdaetsya].

Зотов Георгий. 2015. Печаль варшавянки. Почему в Польше не рады освобождению от фашизма. B http://www.aif.ru/society/history/pechal_varshavyanki_pochemu_v polshe_ne_rady_osvobozhdeniyu_ot_fashizma [Zotov Georgij. 2015. Pechal' varshavyanki. Pochemu v Pol'she ne rady osvobozhdeniyu ot fashizma. V http://www.aif.ru/society/history/pechal_varshavyanki_pochemu_v_polshe_ne_rady_osv obozhdeniyu_ot_fashizma].

Зотов Георгий. 2016. Польская паника. Варшава измучила себя страхом перед «угрозой с Востока». B http://www.aif.ru/politics/world/polskaya_panika_varshava_izmuchila_sebya _strahom_pered_ugrozoy_s_vostoka[Zotov Georgij. 2016. Pol'skaya panika. Varshava izmuchila cebya strakhom pered ,ugrozoj s Vostoka” V http://www.aif.ru/ politics/world/ polskaya_panika_varshava_izmuchila_sebya_strahom_pered_ugrozoy_s_vostoka]. 
Мирзаян Геворг. 2016. Конфликт с Россией как попутный ветер. B http://expert.ru/ 2016/02/9/polsha/ [Mirzayan Gevorg. 2016. Konflikt c Rossiej kak popytnyj veter. V http://expert.ru/2016/02/9/polsha/].

Неменский Олег. 2014. Российско-польские отношения: конец «нормализации». B https://regnum.ru/news/1829783.html [Nemenskij Oleg. 2014. Rossijsko-pol'skije otnosheniya: konets „,normalizatsii”. V https://regnum.ru/news/1829783.html].

Офицеров-Бельский Дмитрий. 2015. Бесконечный спор: Почему в российско-польских отношениях все так сложно? В https://lenta.ru/articles/2015/02/14/polishrelations2/ [Ofitserov-Bel'skij Dmitrij. 2015. Beskonechnyj' spor: Pochemu v rossijsko-pol'skikh otnosheniyakh vsyo tak slozhno? V https://lenta.ru/articles/2015/02/14/polishrelations2/].

Офицеров-Бельский Дмитрий. 2015. Мертвые без погребения. Ответ автора «Ленты.ру» посольству Польши в Москве. В https://lenta.ru/articles/2015/02/10/answer/ [OfitserovBel'skij Dmitrij. 2015. Myortvye bez pogrebeniya. Otvet avtora „Lenty.ru” posol'stvu Pol'shi v Moskve. V https://lenta.ru/articles/2015/02/10/answer/].

Реален ли новый «славянский союз» Польши и России? 2019. B https://news.rambler.ru/other/41567127-realen-li-novyy-slavyanskiy-soyuz-polshi-irossii/ [Realen li novyj ,slavyanskij soyuz" Pol'shi i Rossii? 2019. Vhttps://ne ws.rambler.ru/other/41567127-realen-li-novyy-slavyanskiy-soyuz-polshi-i-rossii/].

Российско-польские отношения: социологический мониторинг 2012-2014. 2015. B https://wciom.ru/fileadmin/file/reports_conferences/2015/2015-03-06-roosia-polsha.pdf [Rossijsko-pol'skie otnosheniya: sotsiologicheskij monitoring 2012-2014. 2015. V https://wciom.ru/fileadmin/file/reports_conferences/2015/2015-03-06-roosia-polsha.pdf]. Сидорчик Андрей. 2017. История большой лжи. Миф и правда о Варшавском восстании. B http://www.aif.ru/society/history/istoriya_bolshoy_lzhi_mif_i_pravda_o_varshavskom_v osstanii [Sidorchik Andrej. 2017. Istoriya bol'shoj lzhi. Mif i pravda o Varshavskom vosstanii. V http://www.aif.ru/society/history/istoriya_bolshoy_lzhi_mif_i_pravda_o _varshavskom_vosstanii].

Сидорчик Андрей. 2017. Казус Качиньского. Все о катастрофе Ту-154 под Смоленском без мифов. В http://www.aif.ru/society/history/kazus_kachinskogo_vse_o_katastrofe_tu154_pod_smolenskom_bez_mifov [Sidorchik Andrej. 2017. Kazuc Katchin'skogo. Vsyo o katastrofe Tu-154 pod Smolenskom bez mifov. http:/www.aif.ru/society/history/ kazus_kachinskogo_vse_o_katastrofe_tu-154_pod_smolenskom_bez_mifov].

Хорев Виктор. 2000. Имагология и изучение русско-польских литературных связей.

В Поляки и русские в глазах друг друга, 22-32 [Khorev Viktor. 2000. Imagologiya i izuchenie russko-pol'skikh literaturnykh svyazej. V Polyaki i russkije v glazakh drug druga, 22-32].

Шторм Александр. 2017. Польские санкции: от экспорта в Россию к импорту из Китая. B https://eadaily.com/ru/news/2017/12/19/polskie-sankcii-ot-eksporta-v-rossiyu-k-importuiz-kitaya [Shtorm Aleksandr. 2017. Pol'skie sanktsii: ot eksporta v Rossiyu k importu iz Kitaya. V https:/eadaily.com/ru/news/2017/12/19/polskie-sankcii-ot-eksporta-v-rossiyu-kimportu-iz-kitaya]. 